\title{
Pemberian Tepung Daun Lamtoro (Leucaena leucocephala) Dalam Ransum Terhadap Organoleptik Daging Burung Puyuh (Coturnix-coturnix Javonica)
}

\author{
Yusrida Siregar, Aisyah Nurmi ${ }^{2}$ \\ ${ }^{1}$ Alumni Fakultas Peternakan Program Studi Peternakan Universitas Muhammadiyah \\ Tapanuli Selatan, e-mail : Siregar.yusrida@yahoo.com \\ ${ }^{2}$ Dosen Program Studi Peternakan Fakultas Peternakan Universitas Muhammadiyah \\ Tapanuli Selatan,e-mail : aisyah.nurmi@um-tapsel.ac.id
}

\begin{abstract}
ABSTRAK
Lamtoro (Leucaena leucocephala) adalah salah satu tanaman yang cukup banyak tersedia dan memiliki kandungan nutrisi cukup tinggi. Daun lamtoro mengandung protein yang dapat di manfaatkan sebagai alternative pakan campuran ransum. Penelitian ini bertujuan untuk mengetahui pengaruh penambahan tepung daun lamtoro dalam ransum terhadap uji organoleptik daging burung puyuh (Coturnix-coturnix jovanica). Rancangan penelitian adalah Rancangan Acak Lengkap (RAL) dengan jumlah perlakuan 6 dan 4 ulangan dengan susunan perlakuan penambahan tepung daun lamtoro LO (0\%), L1 (5\%), L2 (10\%), L3 (15\%), L4 (20\%), L5 ( 25\%). Berdasarkan hasil penelitian untuk uji organoleptik secara mutu hedonik dan hedonik terhadap daging dada burung puyuh yang diberi perlakuan ransum dengan penambahan tepung daun lamtoro menunjukkan pengaruh yang nyata terhadap uji hedonik warna dan untuk mutu hedonik memberi pengaruh yang tidak nyata terhadap warna, rasa, aroma dan tekstur daging dada burung puyuh.
\end{abstract}

Kata kunci : lamtoro, uji organoleptik, burung puyuh.

\section{PENDAHULUAN}

Indonesia merupakan negara yang memiliki banyak keanekaragaman hewan. Salah satu keanekaragaman hewan yang dimiliki Indonesia adalahunggas yang dapat diolah menjadi makanan atau bisa dikonsumsi seperti daging burung puyuh. Daging burung puyuh telah lama dimanfaatkan sebagai bahan pangan, karena burung puyuh memiliki rasa yang cukup lezat dan kaya akan gizi didalamnya sehingga dapat menggantikan ayam maupun bebek.

Burung puyuh merupakan salah satu jenis unggas yang sangat mudah dipelihara, tahan terhadap penyakit, dan jumlah produksi telur yang cukup tinggi, yaitu dapat mencapai 250300 butir per tahun. Selain itu daging puyuh bergizi tinggi dengan kadar protein sekitar $21,1 \%$ dan kadar lemak yang cukup rendah, yaitu hanya sebesar 7,73\% (Tuleun dan Dashe, 2010).

Daging merupakan salah satu bahan pangan yang menjadi sumber protein hewani. Tingginya tingkat konsumsi daging disebabkan nilai gizi yang terkandung di dalam daging lebih banyak bila dibandingkan dengan bahan pangan lainnya. Selain itu, daging mempunyai asam amino essensial yang lebih lengkap bila dibandingkan dengan protein yang berasal dari 
nabati. Pengolahan daging lebih sulit dilakukan karena daging merupakan bahan pangan yang mudah rusak. Penampilan dan kandungan gizi pada daging sangat menentukan kualitas daging itu sendiri. Kualitas daging bisa dilihat dari warna, aroma, rasa, dan keempukan, sehingga perlu dilakukan uji fisik serta uji organoleptik untuk mengetahui rasa daging yang akan di konsumsi.

Banyak hal yang dapat mempengaruhi kualitas daging baik ketika pemeliharaan maupun ketika pengolahan. Faktor yang dapat mempengaruhi kualitas daging selama proses sebelum pemotongan adalah perlakuan dan istirahat yang dapat menentukan tingkat cekaman (stress) pada ternak yang pada akhirnya akan menentukan kualitas daging yang akan dihasilkan. Selain itu, selama pemeliharaan, pakan yang diberikan akan berpengaruh terhadap kualitas daging yang akan dihasilkan dan merupakan salah satu faktor yang sangat penting dalam pertumbuhan. Pakan yang dibutuhkan adalah pakan yang mengadung protein tinggi yang akan berpengaruh terhadap pertumbuhannya, dimana pertumbuhan yang baik akan menghasilkan daging yang ber kualitas baik. Salah satu pakan alternatif yang dapat di gunakan peternak adalah daun lamtoro, dimana daun lamtoro memiliki kandungan protein yang tinggi yang dapat mempermudah peternak dalam penyediaan pakan.

Pengujian organoleptik merupakan pengujian yang didasarkan pada proses pengindraan yaitu indra penglihatan (mata), perasaan (lidah) dan penciuman (hidung). Melalui pengujian organoleptik konsumen (panelis) akan dapat memberikan kesan dari bahan pagan tersebut dan akan diketahui daya penerimaan konsumen terhadap suatu produk.

Diadakannya uji organoleptik pada daging burung puyuh ini adalah untuk mengetahui pengaruh penambahan tepung daun lamtoro (Leucaena leucocephala) dalam ransum terdap uji organoleptik (daging) burung puyuh (Coturnix-coturnix javonica).

\section{MATERI DAN METODE PENELITIAN}

\section{Materi penelitian}

Sampel yang digunakan dalam penelitian ini adalah Ternak yang burung puyuh yang telah dipelihara selama 42 hari sebanyak 120 ekor yang diperoleh dari Poultry Shop Padangsidimpuan dengan sampel daging dada yang digunakan dari setiap perlakuan sebanyak 24 ekor. Panelis sebanyak 15 orang yang berasal dari kalangan mahasiswa Fakultas Peternakan Universitas Muhammadiyah Tapanuli Selatan. Bahan yang di gunakan dalam penelitian tusuk sate, arang, pisau, aquades, roti, tissue, piring, lembar kuisioner. 


\section{Metode penelitian}

Penelitian dilakukan dengan cara eksperimen menggunakan Rancangan Acak Lengkap (RAL) dengan jumlah perlakuan $(\mathrm{t})=6$, ulangan $(\mathrm{n})=4$, dengan susunan perlakuan ransum adalah L0 (Ransum tanpa penambahan tepung daun lamtoro 0\%), L1 (Ransum dengan penambahan tepung daun lamtoro sebanyak 5\%), L2 (Ransum dengan penambahan tepung daun lamtoro sebanyak 10\%), L3 (Ransum dengan penambahan tepung daun lamtoro sebanyak 15\%), L4 (Ransum dengan penambahan tepung daun lamtoro sebanyak 20\%), L5 (Ransum dengan penambahan tepung daun lamtoro sebanyak 25\%).

Analisis data dilakukan berdasarkan analisis keragaman. Bila hasilnya berbeda nyata antara perlakuan, maka akan dilakukan uji beda nyata terkecil atau beda nyata jujur atau uji Duncan's (Mattjik dan Sumerta Jaya, 2002).

KK $<5 \%$ : Uji lanjut pakai Beda Nyata Terkecil (BNT)

$5<\mathrm{KK}<10 \% \quad$ : Uji lanjut pakai Beda Nyata Jujur (BNJ)

KK > 10\% : Uji lanjut pakai Duncan's Test.

\section{HASIL DAN PEMBAHASAN}

Uji organoleptik terhadap suatu bahan pangan merupakan indikator yang dapat menunjukkan tingkat penerimaan konsumen terhadap produk tersebut. Mutu dan tingkat kesukaan konsumen dalam organoleptik daging dada burung puyuh yang diberi ransum dengan tambahan tepung daun lamtoro dalam penelitian ini di ukur berdasarkan warna, rasa, aroma dan tekstur.

\section{Uji Mutu Hedonik}

Rataan nilai hasil penilaian panelis terhadap uji organoleptik warna, rasa, aroma dan tekstur daging burung puyuh dilihat pada Tabel dibawah ini.

Tabel 1 Hasil Penelitian Pengaruh Pemberian Tepung Daun Lamtoro (Lecaena Leucocephala) Dalam Ransum Terhadap Warna, Rasa, Aroma, Dan Tekstur Daging Burung Puyuh.

\begin{tabular}{cllll}
\hline \multirow{2}{*}{ Perlakuan } & \multicolumn{4}{l}{ Parameter } \\
\cline { 2 - 5 } & Warna & Rasa & Aroma & Tekstur \\
\hline L0 & $2,917^{\text {tn }}$ & $4,693^{\text {tn }}$ & $3,117^{\text {tn }}$ & $2,883^{\text {tn }}$ \\
L1 & $2,867^{\text {tn }}$ & $4,240^{\text {tn }}$ & $2,850^{\text {tn }}$ & $2,683^{\text {tn }}$ \\
L2 & $2,950^{\text {tn }}$ & $4,880^{\text {tn }}$ & $3,067^{\text {tn }}$ & $2,750^{\text {tn }}$ \\
L3 & $2,500^{\text {tn }}$ & $4,827^{\text {tn }}$ & $3,117^{\text {tn }}$ & $2,633^{\text {tn }}$ \\
L4 & $2,733^{\text {tn }}$ & $4,613^{\text {tn }}$ & $2,750^{\text {tn }}$ & $2,833^{\text {tn }}$ \\
L5 & $2,967^{\text {tn }}$ & $4,907^{\text {tn }}$ & $2,900^{\text {tn }}$ & $2,783^{\text {tn }}$ \\
\hline
\end{tabular}




\section{Warna}

Tingkat rataan warna daging paling tinggi terdapat pada L5 dengan rataan 2,967 (agak merah) dengan pemberian tepung daun lamtoro dalam ransum sebanyak $25 \%$ dan rataan terendah terdapat pada perlakuan L3 dengan rataan 2,500 (agak pucat) dengan pemberian tepung daun lamtoro dalam ransum sebanyak $15 \%$.

Hasil analisis keragaman menunjukkan bahwa perlakuan pemberian tepung daun lamtoro dalam ransum memberikan pengaruh yang tidak nyata $(\mathrm{P}>0,05)$ terhadap warna daging. Hal ini berarti warna daging dada burung puyuh yang diberi ransum dengan penambahan tepung daun lamtoro sampai $25 \%$ sama bila di bandingkan dengan tanpa pemberian tepung daun lamtoro memberikan pengaruh yang tidak nyata. Hal ini disebabkan pakan yang diberi tidak begitu banyak mengandung lemak yang memberikan pengaruh pada warna daging puyuh, sedangkan faktor pakan, dan perlemakan merupakan salah satu yang memberikan pengaruh terhadap warna daging.

Warna daging dipengaruhi oleh banyak faktor, antara lain umur, jenis kelamin, pakan, lemak, kandungan air, kondisi sebelum di sembelih, hingga pengolahan. warna daging sangat bergantung pada keberadaan pigmen myglobin dan hemogglobin. Perubahan warna terjadi karena jumlah pigmen tesebut berkurang atau mengalami perubahan kimia.

\section{Rasa}

Faktor-fakto ryang mempengaruhi rasa daging antara lain perlemakan, bangsa, umur dan pakan. Selain itu, faktor lain yang juga mempengaruhi adalah proses pemasakan sebelum daging disajikan (Suherman, 1988).

Tabel di atas menunjukkan tingkat rataan tertinggi terdapat pada perlakuan L5 (pemberian tepung daun lamtoro dalam ransum sebanyak 25\%) dengan rataan 4,907 (sangat gurih) dan rataan terendah terdapat pada perlakuan L1 (pemberian tepung daun lamtoro dalam ransum sebanyak 5\%) dengan rataan 4,240 (gurih).

Hasil analisis keragaman menunjukkan bahwa perlakuan memberikan pengaruh tidak nyata $(\mathrm{P}>0,05)$ terhadap rasa daging puyuh. Hal ini disebabkan oleh kandungan pakan yang di berikan pada burung puyuh tidak banyak mengandung lemak yang menyebabkan daging burung puyuh tidak mengandung lemak yang begitu banyak yang dapat berpengaruh terhadap rasa daging dada burung puyuh.

\section{Aroma}

Tabel di atas menunjukkan nilai rataan paling tinggi terdapat pada perlakuan LO( pemberian tepung daun lamtoro sebanyak 0\%) dan L3 (pemberian tepung daun lamtoro sebanyak 15\%) dengan nilai rataan 3,117 (agak amis). Nilai rataan terendah terdapat pada 
perlakuan L4 (pemberian tepung daun lamtoro sebanyak 20\%) dengan rataan 2,750 (agak amis).

Hasil analisis keragaman menunjukkan bahwa perlakuan memberikan pengaruh yang tidak nyata $(\mathrm{P}>0,05)$ terhadap aroma daging burung puyuh. Hal ini di duga disebabkan umur yang terlalu muda dan tipe pakan yang diberikan tidak mengadung banyak lemak sehingga daging yang di hasilkan tidak mengandung lemak yang begitu banyak yang dapat mempengaruhi aroma pada daging, sama halnya dengan rasa karena aroma dan rasa adalah sensasi yang kompleks yang saling terkait.

Faktor-faktor yang mempengaruhi aroma daging adalah umur ternak, tipe pakan, spesies, jenis kelamin, lemak, bangsa, lama waktu dan kondisi penyimpanan daging setelah pemotongan. Kadar lemak dan umur banyak mempengaruhi aroma. Umur ternak yang tua mempunyai aroma yang lebih kuat dari pada daging ternak muda (Amerine et al, 1965).

\section{Tekstur}

Tingkat rataan tekstur daging burung puyuh dari tabel di atas menunjukkan paling tinggi terdapat pada perlakuan L0 (ransum dengan penambahan tepung daun lamtoro 0\%) dengan rataan 2,883 dengan tekstur (agak empuk), sedangkan terendah ada pada perlakuan L3 (ransum dengan penambahan tepung daun lamtoro sebanyak 15\%) dengan rataan 2,633 dengan tekstur (agak empuk).

Hasil analisis sidik ragam menunjukkan bahwa pemberian perlakuan memberikan pengaruh tidak nyata $(\mathrm{P}>0.05)$ terhadap tekstur daging burung puyuh. Hal ini disebabkan tidak berbedanya cara pemeliharaan, umur, dan cara penanganan setelah pemotongan, burung puyuh yang digunakan pada semua perlakuan.

Menurut Desroier (1977), faktor-faktor yang mempengaruhi keempukan daging adalah faktor sebelum pemotongan (ante mortem) dan faktor sesudah pemotongan (post mortem). Ante mortem, yaitu genetik, sifat-sifat biologis, umur, pemberian makan dan pemeliharaan hewan. Post mortem adalah cara pemotongan, lama penyimpanan, suhu penyimpanan, pH, penambahan zat-zat pelunak, metode pengolahan, jumlah lemak yang terdapat diantara jaringan pengikat otot.

\section{Uji Hedonik}

Rataan nilai hasil penilaian panelis terhadap uji organoleptik warna, rasa, aroma dan tekstur daging burung puyuh (coturnix-coturnix javonica) dilihat pada Tabel dibawah ini. 
Tabel 2 Hasil Penelitian Pengaruh Pemberian Tepung Daun Lamtoro (Leucaena Leucocephala) Dalam Ransum Terhadap Warna, Rasa, Aroma, Dan Tekstur Daging Burung Puyuh.

\begin{tabular}{cllll}
\hline \multirow{2}{*}{ Perlakuan } & \multicolumn{3}{c}{ Parameter } \\
\cline { 2 - 5 } & Warna & Rasa & Aroma & Tekstur \\
\hline L0 & $2,767^{\mathrm{a}}$ & $2,683^{\text {tn }}$ & $2,617^{\text {tn }}$ & $2,883^{\text {tn }}$ \\
L1 & $2,967^{\mathrm{a}}$ & $2,617^{\text {tn }}$ & $2,650^{\text {tn }}$ & $2,617^{\text {tn }}$ \\
L2 & $2,500^{\text {ab }}$ & $2,717^{\text {tn }}$ & $2,567^{\text {tn }}$ & $2,700^{\text {tn }}$ \\
L3 & $2,550^{\mathrm{a}}$ & $2,717^{\text {tn }}$ & $2,633^{\text {tn }}$ & $2,683^{\text {tn }}$ \\
L4 & $2,683^{\mathrm{a}}$ & $2,500^{\text {tn }}$ & $2,483^{\text {tn }}$ & $2,017^{\text {tn }}$ \\
L5 & $2,683^{\text {a }}$ & $2,817^{\text {tn }}$ & $2,350^{\text {tn }}$ & $2,767^{\text {n }}$ \\
\hline
\end{tabular}

\section{Warna}

Tingkat rataan paling tinggi terdapat pada perlakuan L1 (penambahan tepung daun lamtoro sebanyak 5\%) dengan rataan 2,967 tingkat penilaian suka, sedangkan nilai terendah terdapat pada perlakuan L2 (penambahan tepung daun lamtoro sebanyak 10\%) dengan nilai 2,500 tingkat penilaian agak suka.

Hasil analisis sidikragam menunjukkan bahwa pemberian tepung daun lamtoro dalam ransum memberikan pengaruh yang nyata terhadap uji hedonik warna daging dada burung

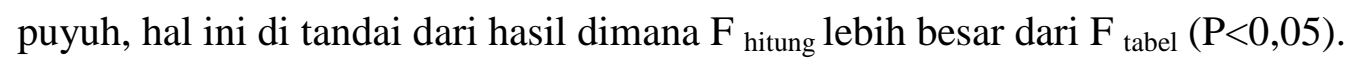

Untuk mengetahui perbedaan antara pelakuan yang memberi pengaruh penambahan tepung daun lamtoro dalam ransum burung puyuh maka dilakukan uji beda rata-rata, dengan koefisien keragaman 7,139 dengan uji lanjut beda nyata jujur (BNJ), sebagai mana tercantum pada tabel di bawah ini. Uji lanjut beda nyata jujur pengaruh perlakuan terhadap uji hedonik warna daging burung puyuh.

Tabel 3 Uji Lanjut Beda Nyata Jujur Pengaruh Perlakuan Terhadap Warna Daging Burung Puyuh.

\begin{tabular}{ccc}
\hline Perlakuan & Rataan & Notasi \\
\hline L1 & 2,967 & $\mathrm{~A}$ \\
L0 & 2,767 & $\mathrm{~A}$ \\
L4 & 2,683 & $\mathrm{~A}$ \\
L5 & 2,683 & $\mathrm{~A}$ \\
L3 & 2,550 & $\mathrm{~A}$ \\
L2 & 2,500 & $\mathrm{Ab}$ \\
\hline
\end{tabular}

Hasil uji lanjut dengan menggunakan uji lanjut Beda Nyata Jujur menunjukkan bahwa perlakuan pemberian tepung daun lamtoro dalam ransum L1 (10\%), L3 (15\%), L4 (20\%), dan L5(25\%) memberikan pengaruh yang tidak berbeda ( $>00,05)$, sama halnya dengan ransum tanpa pemberian tepung daun lamtoro (L0) tidak memberikan pengaruh yang berbeda ( $\mathrm{P}>0,05)$ antara perlakuan L1, L3, L4 dan L5. Lain halnya dengan L2 ransum dengan 
penambahan tepung daun lamtoro sebanyak $10 \%$ memberikan pengaruh yang berbeda $(\mathrm{P}<0,05)$ pada perlakuan L1, L3, L4, L5 dan begitu juga antara L2 dan L0 tanpa penambahan tepung daun lamtoro memberikan pengaruh yang berbeda $(\mathrm{P}<0,05)$. Hal ini disebabkan karena panelis lebih menyukai warna daging yang kemerah-merahan dari pada warna daging yang pucat.

Dalam faktor umur, jenis kelamin, cara pemeliharaan dan pemasakan burung puyuh selama penelitian adalah sama pada setiap perlakuan. Faktor-faktor yang mempengaruhi warna daging antara lain adalah pakan, spesies, bangsa, umur, jenis kelamin, stress, $\mathrm{pH}$ dan oksigen. Semua faktor tersebut merupakan penentu utama konsentrasi pigmen mioglobin daging (Soeparno, 2005).

\section{Rasa}

Rasa merupakan salah satu faktor yang menjadi pertimbangan konsumen dalam memilih jenis makanan. Tingkat rataan penilaian rasa terhadap uji hedonik daging puyuh menunjukkan 2,675 dengan tingkat penilaian konsumen suka. Tingkat rataan daging puyuh tertinggi terdapat pada perlakuan L5 (penambahan tepung daun lamtoro sebanyak 25\%) dengan rataan 2,817 tingkat penilaian konsumen suka dan tingkat terendah terdapat pada perlakuan L4 (penambahan tepung daun lamtoro sebanyak 20\%) dengan nilai rataan 2,500 (agak suka).

Hasil analisis keragaman menunjukkan bahwa perlakuan memberikan pengaruh tidak nyata $(\mathrm{P}>0,05)$ terhadap rasa daging burung puyuh. Keadaan ini menunjukkan bahwa pemberian tepung daun lamtoro dalam ransum sampai $25 \%$ tidak mempengaruhi rasa daging dada burung puyuh. Selain itu pada masing-masing perlakuan digunakan strain dan umur burung puyuh yang sama selama pemeliharaan. Proses pemotongan, penyimpanan dan pemasakan daging juga dilakukan dengan cara yang tidak berbeda. Sesuai dengan yang dikemukakan oleh (Snyder dan Orr, 1964), bahwa faktor-faktoryang mempengaruhi rasa daging antara lain perlemakan, bangsa, umur dan pakan. Selain itu, faktor lain yang juga mempengaruhi adalah proses pemasakan sebelum daging disajikan.

\section{Tekstur}

Hasil penilaian menunjukkan tingkat rataan paling tinggi terdapat pada perlakuan L4 (penambahan tepung daun lamtoro sebanyak 20\%) dengan rataan 3,017 (suka) dan rataan terendah terdapat pada perlakuan L1 (penambahan tepung daun lamtoro dalam ransum sebanyak 5\%) dengan rataan 2,617 (suka).

Hasil analisis keragaman menunjukkan bahwa perlakuan memberikan pengaruh tidak nyata $(\mathrm{P}>0.05)$ terhadap tekstur daging burung puyuh. Hal ini kemungkinan disebabkan oleh 
tidak berbedanya strain, umur, cara pemeliharaan, penanganan waktu pemotongan serta pasca pemotongan.

Tekstur merupakan penentu yang paling penting pada kualitas daging. Keempukan daging adalah kualitas yang sudah di masak berdasarkan sifat kemudahannya dikunyah. Tingkat kekerasan tekstur meningkat dengan bertambahnya umur, otot ternak jantan mempunyai tekstur yang lebih besar dari pada otot ternak betina, bangsa ternak juga mempengaruhi tekstur otot (Bandall, 1973).

\section{Aroma}

Hasil penilaian tingkat rataan aroma daging puyuh tertinggi ada pada perlakuan L1 (penambahan tepung daun lamtoro sebanyak 5\%) dengan rataan 2,650 (suka) dan tingkat rataan terendah ada pada perlakuan L5 (penambahan tepung daun lamtoro sebanyak 25\%) dengan rataan 2,350 (agak suka).

Hasil analisis keragaman menunjukkan bahwa perlakuan memberikan pengaruh tidak nyata $(\mathrm{P}>0,05)$ terhadap aroma daging burung puyuh. Hal ini kemungkinan disebabkan oleh kadar perlemakan dan umur yang tidak berbeda pada daging dada burung puyuh dari setiap masing-masing perlakuan. Seperti yang dikemukakan Amerine et al. (1965), bahwa kadar lemak dan umur banyak mempengaruhi aroma. Umur ternak yang lebih tua mempunyai aroma yang lebih kuat daripada daging ternak muda.

\section{KESIMPULAN}

Berdasarkan hasil penelitian dapat disimpulkan bahwa untuk uji organoleptik secara mutu hedonik dan hedonik terhadap daging dada burung puyuh yang diberi perlakuan ransum dengan penambahan tepung daun lamtoro memberikan pengaruh yang nyata terhadap uji hedonik warna dan untuk mutu hedonik memberi pengaruh yang tidak nyata terhadap warna, rasa, aroma dan tekstur daging dada burung puyuh. Hasil penilaian dapat di simpulkan daging dada burung puyuh untuk warna daging agak merah (suka), rasa sangat gurih (suka), aroma agak amis (suka) dan tekstur agak keras (suka). Karakteristik tersebut tidak berbeda dibandingkan dengan ransum tanpa pemberian tepung daun lamtoro. Secara umum bagian dada burung puyuh disukai panelis dan dengan keadaan ini berarti bahwa tepung daun lamtoro dapat di manfaatkan sebagai alternatif pakan lokal sumber protein. 


\section{DAFTAR PUSTAKA}

Amerine, M.A. R.M. Pangborndan E.B.Roessler. 1965.Principles of sensory Evaluationof Food. Academic Press, NewYork.

Bendall, J.R. 1973. The Structure and Function of Muscle. Vol. 2 Ed. G.H. Bourne. Academic Press, New York. pp. $244-309$.

Desroier, N.W. 1977. Meat Technology Elementsof Food Technology, AVI Publidhing Compaby, Inc., Westport, Connecticut. pp. $314-353$.

Lawrie, RA. 2003. Ilmu Daging. Cetakan Keempat. Penerjemah: Aminuddin Parakkasi. Universitas Indonesia Press, Jakarta.

Manurung, T .1996 . Penggunaan hijauan leguminosa pohon sebagai sumber protein ransum sapi potong. Jumal Ilmu Ternak dan Veteriner . 1(3) :143-147.

Mattjik, A. A. Dan I. M. Sumertajaya. 2002. Perancangan Percobaan Dengan Aplikasi. EdisiRevisi. Penebar Swadaya. Jakarta.

Sayuti, 2006.Ilmu Teknologi Daging. Gajah MadaUniversitas Press. Yogyakarta

Snyder, E.S. and H.L. Orr. 1964. Poultry Meat.Ontario Department of Agriculture. Parliament Buildings. Toronto.

Steel.R.G.D. Dan Torrie, 1991. J.H. Principles And Procedures Of Statisties. Mc. Grow. Hil Book Co. Inc. Newyork.

Soeparno. 2005. Ilmu dan teknologi danging,cetakan III. GadjahMada University Press.Yogyakarta.

Tuleun C.D, and N.A Dashe. 2010. Effect of dietary levels of toasted mucuna seed meal (tmsm) on the performance and egg quality parameters of laying japanese quails (Coturnix-coturnix japonica). Int J Poult Sci. 9(12):1092-1096. 